\title{
LANDSCAPES OF PARADOX: PUBLIC Discourses AND POLICIES IN POLAND's RELATIONSHIP WiTH THE NORD STREAM PIPELINE ${ }^{1}$
} STEFAN BOUZAROVSKI (s.bouzarovski@gmail.com)
MARCIN KONIECZNY

\footnotetext{
${ }^{1}$ Part of the background research for this paper has been supported by the Ministry of Education, Youth and Sports of the Czech Republic, project no. MSM0021620831:

'Geographic Systems and Risk Processes in the Context of Global Change and European Integration'. The authors wish to thank Mark Bassin and Shannon O'Lear for their helpful comments on previous versions of the paper. All errors and omissions should be attributed solely to the authors.
} 


\section{LANDSCAPES OF PARADOX: PUBLIC DiscouRseS AND POLICIES IN POLAND's RELATIONSHIP WiTH THE NORD STREAM PIPELINE}

The announcement that the Russian state-owned gas monopoly Gazprom and two German energy companies intend to construct a new undersea Baltic pipeline that will bypass Poland has raised a fierce political storm in that country. In this paper, we aim to shed further light onto the forces that govern the proposed pipeline's interaction with Poland's energy, economic and geopolitical landscapes, by examining some of the public discourses and state policies that have been associated with the country's reaction to it. One of our key findings is that the new gas link - recently named Nord Stream - is creating interlocking webs of socio-spatial paradoxes and contradictions that reverberate across the entire Baltic space. In the process, they simultaneously bind together and tear apart the territorial and political fabric of the region.

Few events in the recent history of the Baltic region have caused as much controversy as the announcement, made in April 2005, that a German energy company had signed an agreement with the Russian gas monopoly Gazprom to construct a new direct undersea pipeline between the two countries. 'Nord Stream', as it is now called, quickly became a new source of geopolitical tension in the region, having been met with sharp criticism by public officials in the countries that would be bypassed by it. In Poland, national politicians called Nord Stream a 'geopolitical disaster' and a 'Russian-German conspiracy', ${ }^{i}$ while the Estonian president warned the EU that over-reliance on Russian gas is 'simply not rational' and that large-scale dependence on Russia's energy supplies 'involves high levels of risk'. ii

Three years down the line, and the political storm raised by Nord Stream shows no sign of abating. Despite the powerful energy interdependencies and financial interests behind it, the developers' plans for the pipeline have been constantly dogged in environmental, political and economic problems.iii This may be attributed to the strength of Nord Stream's vocal opponents, who insist that the pipeline will draw a new border across Europe, thus disrupting energy transit routes between Eastern and Western European states. As a result of the fact that 'it is hard to say where Gazprom ends and the Russian state begins', iv they argue, Western European countries like Germany 'would be connected directly to the Russian valves, while the others would be left alone, hoping for Russia's mercy'. In part, such fears have been inspired by Russia's decisions to temporarily shut off gas supplies to Ukraine and Belarus as a result of bilateral energy disputes during several consecutive winters, with the most dramatic such episode taking place during early 2009. vi There has 
also been widespread opposition to the pipeline on environmental grounds, as it is feared that the new object may disrupt the sensitive ecosystems of the Baltic Sea.vii

However, Nord Stream's supporters emphasise its positive economic impacts: they claim that the new link will diversify the EU's natural gas import pathways, thus enhancing the security of Europe's energy supply as a whole. The pipeline is also purported to bring economic benefits to the communities along its route, thanks to improvements in local infrastructure, and the involvement of subcontracting companies at various levels. viii

For all the media hype it has attracted and public controversies that it has provoked, however, Nord Stream remains grossly understudied within the academic literature. In particular, there is an insufficient understanding of the complex ways in which the pipeline is embedded within broader relations of geopolitical and economic power in the region. Theoreticallyinformed research of the institutional and spatial networks surrounding the new gas link is also lacking, in spite of the extensive news coverage and think tank analyses that it has attracted. This is especially true in the seven Baltic countries that flank the proposed route of Nord Stream, and are bound to be directly affected by it. Among them, Poland in particular has seen extensive media interest and a considerable re-think of national policy priorities as a result of the pipeline. To a certain extent, this situation can be attributed to its historically difficult political relationship with Germany and Russia - host countries of the companies constructing the pipeline - as well as Poland's important position on the energy transit corridor between Eastern and Western Europe.

In light of such circumstances, then, this paper aims to shed further light on some of the public discourses, power relations and geopolitical dynamics related to the construction of Nord Stream, through a case study of the Polish state and public's reaction to the pipeline. In particular, we are interested in the pipeline's role in the articulation of national security interests and international relations strategies in the Baltic region, as well as its effects on the transformation of energy and national development priorities within Poland itself. We would like to use this interrogation as a first step towards addressing a wider analytical question, pertaining to the manner in which gas pipelines influence, embody and reflect relations of discourse and power across transnational political spaces.

The paper is based on an in-depth review of news sources, policy reports and interviews with decision-makers in Poland. The choice of research location and methods was motivated by the observation that the pipeline appears to be creating new socio-spatial and political contradictions in this country, as well as the Baltic region more widely. Although the international undersea portion of Nord Stream is still a 'phantom' object, 
existing only on the drawing boards and investment plans of the companies involved in it, there is evidence to suggest that the very possibility of its construction is already impacting state policies - and, subsequently, infrastructure investment and economic development patterns - in Poland and the Baltic alike. This implies that a sociopolitical network built around a technical structure which is still physically 'invisible' in the material landscape is in fact already becoming deeply implicated in the shaping of state policy, and thus, indirectly, the physical spaces around it. Moreover, although the pipeline is meant to be connecting two geographical realms through a new co-dependent link, it has in many ways led to new divisions among the countries in its direct vicinity. The paper thus claims that Nord Stream is tearing apart the geopolitical and economic tissue of the Baltic, just as it is forging new connections and bridging new distances.

In wider terms, we are interested in the different ways in which energy pipelines may project the underlying socio-technical matrices of their constituent energy flows into the material and political spaces that host them. Therefore the paper is conceptualised in the vein of, and builds on previous scholarship undertaken within, the fields of critical resource geographyix and science and technology studies (STS). ${ }^{x}$ Following from the work of authors such as Thomas Hughes, Jane Bennett, Susan Leigh Star and Shannon O'Lear, ${ }^{x i}$ we aim to shed further insights on the processes through which energy infrastructures become inscribed into a regional 'landscape of power'. Within the given context, we are particularly interested in the intersection between national-scale political and ideological narratives, on the one hand, and the spatial, political and discursive articulation of what Leslie Dienes terms 'archipelago Russia', xii on the other. In connecting the materiality of pipelines with international politics, xiii we emphasise that the energy circulations hosted by such networks should not just be seen as technical formations that are borne out of particular political-economic conditions, but rather as active agents in the creation of state policy and development patterns.

\section{GAS PIPELINES BETWEEN RUSSIA AND EUROPE: THE REGIONAL CONTEXT}

The institutional and economic contingencies that are implicated in the construction of Nord Stream are part of a broader dynamic of power that engulfs not only the Baltic region, but also the entire ensemble of Russian geopolitical relations with neighbouring states in Europe and Asia. Much of the research in this field has been interested in the different ways in which state and business elites have interacted in the shaping of energy investment decisions, taking pipeline construction in the Caspian basin where such entanglements are both extremely complex and publicly visible - as an example. ${ }^{\text {xiv }}$ It is being increasingly argued that Russian policy in this region has changed since the 1990s, having become more assertive and comprehensive in its use of economic and territorial 
instruments towards particular political goals, while being increasingly driven by pragmatic considerations instead of strategic ones. ${ }^{\mathrm{xv}}$ In this context, it should also be pointed out that there is a significant body of work on the multiple ways in which the Russian energy sector has been transformed from a supporting factor of the Soviet military-industrial complex into a mechanism of soft power that allows this country to extend its influence over the states which source their hydrocarbons from it. ${ }^{\text {vi }}$ However, Russia's ability to act as an energy 'superpower' in the Eurasian realm has often been put into question as a result of the continuing legacy of infrastructural under-investment, the untransparent legal regulation and management structures of energy companies, as well as physical limits on the future availability of oil and gas resources that it possesses. ${ }^{\text {xvii }}$

Regardless of the complex technical and economic issues surrounding the supply of Russian oil and gas to neighbouring states, it is without doubt that energy transit issues have played an important role in the articulation of geopolitical relations between Russia and Europe. Thanks to its strategic spatial location, the Baltic region has become a focal point for the public manifestation of such linkages, and their associated tensions. To a certain extent, this situation can be attributed to the complex power dynamics between Baltic states and Russia. ${ }^{\text {xviii }}$

The central importance of energy diplomacy in this context is evidenced by the results of a recent analysis undertaken by the European Council of Foreign Affairs, a Brussels-based think tank which finds that energy dependence is the central component of the various Baltic states' political and economic partnerships with Russia. The study describes Poland and Lithuania as 'new cold warriors' that have developed an openly hostile relationship with Moscow as a result of, inter alia, the lack of co-operation in the energy sector. At the same time, Estonia, Latvia and Sweden are termed 'frosty pragmatists', because despite maintaining strong business ties, the governments of these countries have often experienced political difficulties with Russia, often linked to questions of energy trade and transit. But Finland - a country highly dependent on Russia for its hydrocarbon imports - is a 'friendly pragmatist': its policies in this domain have been more closely aligned with economic forces, which means that this country has opted for the 'path of least resistance' in political disputes. At the same time, Germany is a clear 'strategic partner' of Russia, because its government has built a strong bilateral relationship with this country, often undermining common EU objectives. ${ }^{x i x}$

Indeed, the manner in which Russian involvement in the patterns of energy consumption, transmission and demand within the EU has exposed the internal weaknesses of the 25-nation bloc has frequently attracted public and expert interest. Although it is not difficult to find news and policy reports arguing that Russia's pipeline diplomacy in the Baltic and Balkan regions is rupturing the internal political and spatial 
cohesion of the EU - thus revealing the bloc's inability to formulate and implement a common energy policy ${ }^{\mathrm{xx}}$ - opposite opinions also exist: it has been claimed that the existence of 'special relationships' between, respectively, Germany and Poland, on the one hand, and Poland and Ukraine, on the other, has led to an improved energy dialogue between the latter two and the EU, because the former two have sought the EU's support for infrastructure projects relevant to the special relationships themselves. ${ }^{x x i}$ Nonetheless, there is widespread opinion that international mechanisms that are already in place - such as the EU-Russia Energy Dialogue - have generally failed to address the key political issues surrounding the institutional and infrastructural aspects of energy flows from Russia to Europe. xxii This is illustrated, for example, by the EU's continued inability to persuade Russia's to sign the Energy Charter Treaty, xxiii although, to cite Andrei Belyi, this document 'represents a very innovative legal framework for energy relations that include trade, transit, investments and energy efficiency issues'. ${ }^{x x i v}$

The need for formulating a common energy policy at the level of the EU is all the more pronounced in light of the bloc's increasing dependence on gas imports. It is projected that the share of this fuel in the EU's total energy mix will inevitably reach the 30 per cent mark over the next 20 years, principally because of the growing role of gas in electricity generation. As a result, the quantity of gas imports in 2030 is expected to exceed its current value by at least 200 per cent. xxv The EU will thus require a major expansion of its gas import capacity, part of which inevitably has to involve the construction of new pipelines from Russia - a country that currently accounts for a quarter of the bloc's energy needs. But this is far from a simple undertaking, considering that the European gas market is one of the world's most complex in terms of the number of international participants: more than 47 per cent of the gas consumed in Western Europe crosses at least two borders before reaching its final destination. xxvi Adding to the EU's woes in the import of piped gas from Russia are the numerous economic disincentives for the routing of new pipelines in this direction - some economic models suggest that the price of gas would decrease in the case of co-operative behaviour between Russia and Ukraine ${ }^{\mathrm{xxvii}}$ - as well as economic models showing that gas companies in the Former Soviet Union would reap higher financial benefits if they chose to direct their gas towards Asia rather than Europe. ${ }^{\text {xxviii }}$

Thanks to its large technical capacity, complicated institutional framework and problematic geographical location in the middle of the Baltic region, the Nord Stream pipeline embodies many of the difficult issues surrounding European gas imports from Russia. Although discussions relating to the project (which was initially called the 'North European Gas Pipeline') started as early as 1993, it was only in 2002 that the idea was taken on board by the EU and declared an investment priority, having subsequently received the declarative support of the 
European Bank for Reconstruction and Development. However, the pipeline entered the public eye only after it was announced, on the $11^{\text {th }}$ of April 2005, that Russia and Germany had signed an agreement to construct it. This was followed by the establishment of a joint venture between the Russian company Gazprom, which would take a 51 per cent share, and Germany's Wintershall and E.ON, each with a 24.5 per cent stake. ${ }^{x x i x}$ Still, except for the overland portion of the pipeline in Russia's Leningrad Oblast, Nord Stream has only existed on paper until now: it has been reported that the company which will build it (Nord Stream AG) is based in Switzerland and will not be physically involved in the construction process itself, having chosen to rely on subcontractors instead. ${ }^{\mathrm{xxx}}$

The pipeline is projected to run for $1200 \mathrm{~km}$ along the Baltic Seafloor, initially carrying up to $27.5 \mathrm{Bcm} /$ year; this is set to double in the near future with the construction of a second, parallel line, thus increasing the share of Russian gas in the EU's energy supply by as much as 40 per cent. As such, Nord Stream will be the largest infrastructural undertaking of its kind in Baltic waters, and the only one to cut across the entire sea in an East-West direction. The pipeline should be supplied with gas from fields in Western Siberia (the Yuzhno-Russkoye deposit), although it is possible that its energy source may also involve the Shtokmanskoye and Yamal fields, which lie further north. Besides the main route running along the bottom of the Baltic Sea, the planned physical infrastructural components of the pipeline also involve a compressor station in the middle of the sea, ${ }^{\mathrm{xxxi}}$ as well as possible spurs to Sweden, Latvia, Denmark, in addition to Belgium, Netherlands, and the UK. According to the most recently available blueprint, the pipeline would pass through the territorial waters of Russia and Germany, as well as the Exclusive Economic Zones (EEZs) of Finland, Sweden, and Denmark.

As pointed out above, reactions to Nord Stream among neighbouring states have been far from favourable. Many of them - most notably Sweden, Lithuania, Poland and Estonia - have expressed serious concerns about its environmental implications, asking for full environmental impact assessments (EIAs) under the auspices of relevant international agreements.xxii Finland and Latvia have also supported the positions of their Baltic neighbours, despite keeping a lower profile with respect to the project, possibly due to the strength of their own energy and political ties with Russia. xxxiii The officials of the former four countries have argued that the pipeline will seriously disrupt the delicate physical, chemical and biological balance of aquatic ecosystems, while exerting direct impacts on ecologically sensitive parts of the seabed and coastal zone. This is because Nord Stream is projected to traverse known repositories of discarded weapons and chemical waste, and there is a danger that the construction process itself may dislodge polluted sediments off the seabed and onto the surrounding countries' beaches. ${ }^{\text {xxiv }}$ Nord Stream would also skirt the 
eastern edge of the Swedish island of Götland, a highly sensitive area on UNESCO's world heritage list. ${ }^{\mathrm{xxx}}$

Political discussions about the environmental and energy security implications of the pipeline have been taken to the European Parliament, whose Petitions Committee, as it was recently reported, received 30,000 signatures on petitions relating to the project, mainly from the Baltic States. ${ }^{x x x v i}$ As a result of the environmental opposition to the pipeline among neighbouring states, Nord Stream has yet to receive construction permits from any of the countries surrounding its intended route. ${ }^{\mathrm{xx} x v i i}$ The Estonian's polity extremely negative reaction to the pipeline forced the Nord Stream consortium to move its initially-intended route out of Estonian waters and into the Finish EEZ.xxxviii Due to fierce environmental opposition in Sweden, Nord Stream AG have abandoned plans to build a service platform in the Swedish EEZ - according to the most recently announced plan, pipeline maintenance will be undertaken through the deployment of 'intelligent pipeline inspection gauges' instead of a fixed platform. ${ }^{\text {xxxix }}$ The pipeline has also become victim of a long-standing territorial dispute between Poland and Denmark, having been forced to change its initially-planned route as a result of continuing bilateral disagreement over the maritime boundary between the two countries. ${ }^{x l}$

In their entirety, these issues illustrate the sheer extent of political determination and economic capital that will be required in order to introduce Nord Stream to the existing socio-technical network of energy flows in the region. However, despite the reported 50\% increase in construction costs - from 5 to 8 billion Euro - and a one-year delay in the date when the pipeline is expected to become operative (from 2010 to 2011), the project consortium doesn't seem to have any intentions to abandon its plans. xli Thus, it was recently reported that Nord Stream AG signed an agreement with the French company EUPEC for the supply of concrete coating and logistics services for pipeline project. As a result, EUPEC has already started constructing a concrete weight coating yard in Germany, with four similar facilities being planned for Sweden and Finland.xlii Nord Stream AG has also announced that it will follow state-of the art technical standards and procedures in the construction and maintenance of the pipeline, xlii while accepting the full terms of the Espoo convention, which obliges it to undertake a wide-ranging environmental impact consultation process across the entire Baltic region. In August 2008, it was reported that the Nord Stream consortium had published a 536-page 'White Book' xliv as a precursor to the full EIA report of the pipeline, due for publication in March 2009. ${ }^{x l v}$ The originally-intended publication date for the EIA was April 2008. xlvi

\section{POLISH NATIONAL IDENTITY AND ENERGY SECURITY DISCOURSES LINKED TO NORD STREAM}


Public discourses surrounding the Nord Stream issue in Poland have been heavily influenced by this country's historically difficult relationship with Russia, as well as the geopolitical complexity of its energy supply patterns. In this context, it should be pointed out that, at present, almost $2 / 3$ of Poland's primary energy consumption is based on domestically-mined coal - clearly an unsustainable pattern in light of the high economic and environmental costs of this fuel. At the same time, Russia provides almost $2 / 3$ of the country's gas imports, with Gazprom holding a 50 per cent stake in the company that supplies most of the remainder, originating from Central Asia. ${ }^{x l v i i}$ The diversification of energy supplies has therefore been a key priority of successive governments, and a highly contentious political issue in the country. ${ }^{\text {xlviii }}$

Thus, when the Polish state-owned gas monopoly (Polskie Górnictwo Naftowe i Gazownictwo, or PGNiG) signed a long-term gas supply agreement with Gazprom in 1996, the leftist government of the time hailed it as the 'contract of the century' that would ensure uninterrupted gas deliveries for almost two decades. Simultaneously, however, the conservative opposition dubbed the contract a new 'gas Yalta', mainly because it increased Poland's dependence on Russian energy imports. ${ }^{\text {xlix }}$ The agreement itself was closely linked to the building of the YamalEurope pipeline - a joint Polish-Russian venture aimed at transporting up to $33 \mathrm{Bcm}$ of Russian gas per year across Belarus and Poland towards Germany. This pipeline, whose construction started soon after the agreement was signed, gave Poland considerable leverage in the mediation of regional energy relations, while bringing new revenue from transit fees. But it also became associated with numerous political and economic controversies, which, it may be argued, eventually contributed to Gazprom's decision to construct Nord Stream.

Although Yamal-Europe began operations in 1999, it only reached full capacity in 2006, mainly due to Polish-Russian disagreement over the financing of two additional compressor stations needed for the full quantities of gas to be transported through the pipe. The pipeline also attracted controversy with respect to the amount of Russian gas that Poland would be obliged to buy under the terms of the 1996 agreement, as it quickly emerged that the energy demand calculations that had provided the basis for the originally negotiated quantities were too high. YamalEurope was also dogged by disagreement about the lease of land from local farmers, the levels of transit fees and taxes charged by the Polish authorities, as well as Gazprom's failure to consult the Polish side about the addition of a fibre optic cable onto the entire length of the pipeline.

At the same time, the Polish government resisted Gazprom's proposals to build a second gas pipeline of a similar size that would enter the country from Belarus and continue to Slovakia, thus avoiding Ukraine - a key Polish ally in the region. Although the plans for this 'bypass' pipeline were eventually withdrawn, and an agreement over the reduction of gas supply 
was reached in February 2003, the final legal resolution of such problems also relieved Gazprom of any obligations to double the capacity of YamalEurope: under the terms of the original agreement, a second line, running parallel to the first and with the same capacity, was supposed to become operational by 2002 .

It is important to note that Russian officials kept announcing the possible construction of a new undersea Baltic gas pipeline throughout the various conflict episodes linked to Yamal-Europe and other energy-related geopolitical tensions in the region. Indeed, as pointed out above, the EU was fully aware of the project, and had officially backed it as early as 2000. ${ }^{1}$ The Russian desire to build new energy and transport linkages that would bypass its neighbours in Eastern and Central Europe (ECE), rather than increasing the capacity of existing infrastructures through these countries, can be seen as part of a broader policy to reduce the bargaining power and economic profits of transit states in territories that, to cite Juhani Laurila, 'formerly belonged to the Soviet Union but are no longer "ours". li While it has been claimed that such a policy closely matches Russia's autarky and national security strategies in the region, it has also been purported to bring practical benefits, as well: for example, Nord Stream officials have claimed that underwater pipelines can provide a cheaper and easier method for transporting pressurised gas, due to not requiring any interim compressors. In addition, they are relieved of the legal and technical difficulties associated with building the pipes through populated areas and natural surface features. ${ }^{\text {lii }}$ It is also true that a pipeline built through international waters would avoid the need for fee payment to transit states, although there is little agreement over whether this would be sufficient to offset its high capital and operating expenses. liii

However, as claimed by Andreas Heinrich, such declarations were never taken very seriously in Poland: the country's politicians and media outlets tended to consider them more as a political bluff than an actual investment intention, considering the excessive investment costs and technical difficulties that an underwater pipeline would be associated with. liv This may explain why Gazprom's signing of a 'Memorandum of Understanding' for the mutual building of the pipeline with BASF/Wintershall in April 2005 - soon to be joined by Ruhrgas and accompanied by the initiation of construction work on the overland section of the pipeline in Russia - came as a major shock to the Polish public and politicians alike. The announcement prompted a very unsympathetic reaction in Poland, whose media outlets and experts immediately started to speculate about the 'real' reasons behind Gazprom's decision to build Nord Stream, often invoking grand historical narratives of national identity and security. At the same time, the country's political leaders started to challenge the initiative within different international fora. ${ }^{\mathrm{lv}}$

Poland's fierce opposition to Nord Stream was embodied by the official reaction of the country's government, whose constituent bodies attacked 
the pipeline proposal on multiple grounds, using a wide range of institutional channels. Having warned the public that Nord Stream threatened the energy security of Poland, the Ministry of Economy expressed serious concerns about its potential environmental impacts, asking for a full internationally-based EIA. A senior member of the Foreign Ministry also stated that the new gas link must meet all European standards for environmental protection, aside from pointing out that the pipeline countered the 'energy solidarity' principles of the European Union. lvi Some of these positions were further elaborated in a well-publicised letter by the Defence Minister's letter to the Financial Times. ${ }^{\text {lvii }}$ In it, he underlined the 'absurdity' of the pipeline's estimated costs, which would be three to five times higher than those required for doubling up existing land links. He warned that German and other EU producers and consumers might eventually have to foot the bill for the increased energy costs and fossil fuel use brought about by the pipeline, while lending themselves to increased market dominance by Gazprom and its allies. The Minister also objected to the rising energy dependence on Russia created by Nord Stream, which, as he argued, would increase this state's political control over different EU member states.

Thus, the official reaction of the Polish polity to the pipeline mainly revolved around its territorial aspects, as it was felt that choice of an undersea route reflected the hidden political, rather than overt economic intentions of the companies behind it. The country's leadership kept stressing that Gazprom's motivation for constructing Nord Stream extended beyond its primary purpose - the transport of Russian gas to Western European markets - into a clandestine geopolitical agenda aimed at increasing the Russian state's political control over the EU. Their main concern in this respect was the decoupling of 'obedient' from 'disobedient' European states which the pipeline could potentially bring about, since it would give Russia the ability to selectively direct gas flows towards individual countries in Eastern and Western Europe. Therefore, it was argued that Nord Stream would reduce not only Poland's but also Europe's energy security. Compounding this political argument over the route of the pipeline was an environmental one, which emphasised the potentially dangerous ecological consequences of the chosen pipeline route. ${ }^{\text {.viii }}$

Parts of the Polish press took some of these claims even further by referencing them with the broader geopolitical context of the Russia/Germany/Poland triangle. One of the most common discourses in this respect was concerned with the relationship between Nord Stream, on the one hand, and Poland's role in the Orange revolution in the Ukraine, on the other. It was often pointed out that the 'real' reason for Russia's choice of the undersea route lay in its government's desire to 'punish' Poland for its own role in the Ukrainian events, whose outcome decreased Russian political influence in that country. ${ }^{\text {,ix }}$ Moreover, the Polish press and politicians alike made numerous references to the pipeline's alleged role in reproducing the old German-Russian geopolitical axis at the 
expense of Poland:lx the consequences of past realpolitik alliances, such as the Molotov-Ribentrop pact, were often invoked in this regard.

In this context, it is worth noting that the more left-leaning, liberallyminded part of the Polish polity has sometimes disagreed with such views, stressing that the country's government is wasting a lot of unnecessary political energy on the issue, and losing its international credibility by engaging with the Nord Stream question in a negative manner. ${ }^{\mathrm{x} i}$ This point of view was epitomised in a recent statement by the former Polish President Aleksandar Kwasniewski: he commented that the Nord Stream issue should be 'depoliticised' and interpreted in the context of Europe's need for a common energy policy, emphasising that the pipeline could provide steady energy supplies for Poland if the country decided to join it. However, his opinions were heavily criticised by both the opposition and government in Poland, with the head of the parliamentary caucus of the right-wing Law and Justice party labelling them 'scandalous' and 'extremely harmful'. .xii

The fierce political opposition and grand historical narratives provoked by the Nord Stream pipeline gradually became inscribed in the articulation of Poland's international relations. The numerous public controversies surrounding the new gas link added further strain to the already difficult relationship between Poland and Russia, which had been weighed down by the latter's banning of Polish meat imports, and the former's veto of the EU-Russia partnership agreement. ${ }^{\text {lxii }}$ In effect, the Nord Stream issue became a practical instrument for the implementation of foreign policy objectives, and the trade-offs implicated in the resolution of these issues. The territorialities of the pipeline - mainly reflected in the political and economic considerations involved in the choice of its intended route across the Baltic Sea - thus came to epitomise a much wider force field of social, technical and geopolitical networks in the region.

\section{NORD STREAM'S INFLUENCE ON POLISH STATE POLICY}

Aside from its growing importance in the domain of foreign policy and international political relations, Nord Stream also left its mark on the formulation of national development policies and energy investment initiatives in the Baltic region. As a result, the political discourses provoked by a non-material object that has existed only in the minds of its planners gradually became embedded into a specific set of policy initiatives aimed at transforming the material realities of surrounding regions and cities. In the case of Poland, it is worth mentioning that some of these initiatives were on the drawing board well before the official announcement for the construction of Nord Stream. The pipeline gave them a new public impetus and increased their strategic significance, since it emboldened the projects' proponents with new arguments about the need for an urgent diversification of Polish energy supplies. ${ }^{\text {lxiv }}$ 
Thus, in late 2006, PGNiG decided to build a Liquified Natural Gas (LNG) terminal in the port of Świnoujśćie, located next to an older, commercial port near the German border. The new terminal, which is expected to start working in 2011, was projected to receive vessels with a total deadweight tonnage of about 70,000, transporting approximately $145,000 \mathrm{~m}^{3}$ of liquefied gas per year. Considering that its total investment cost is at least 350 million Euro, different Polish ports competed fiercely over the location of the project. According to the port authority which won the bid to host the terminal, Świnoujśćie won the bid thanks to a number of safety, economic and strategic considerations, such as, for example, the possibility of a future interconnection with new gas pipelines that would traverse the area. ${ }^{\mathrm{lxv}}$ As stated by the Polish prime minister of the time, the LNG terminal would provide an alternative supply of energy for the country, and was therefore a top investment priority. However, the press has often connected these statements with the political tensions surrounding Nord Stream and Yamal-Europe, especially since it is unclear whether the terminal will ever turn a profit due to its high capital costs. ${ }^{\text {lxvi }}$

The decision to reactivate plans for the construction of nuclear power plant, originally abandoned in the early nineties, can also be seen in this context. Poland adopted an official policy to resume its nuclear energy production programme already in 2004, although it was never specified where any new nuclear plants would be built - and especially whether they would be on the site of the infamous Żarnowiec, whose construction was interrupted half-way and the reactors sold to Finland and Hungary as a result of fierce public protest. lxvii What is much more clear, however, is the active role that Poland would take in the building of a new nuclear station to replace the soon-to-be-decommissioned Ignalina in neighbouring Lithuania. lxvii To facilitate the increased transfer of electricity between the two countries that would ensue after the construction of the station, Poland and Lithuania agreed to build a new 237 million Euro interconnection of their power grids, which would involve the construction of 154 kilometre high-voltage double-circuit power transmission line between the two countries, to be completed by 2015 'at the latest'. While this part of the investment is expected to be financed by the EU, the two states also pledged to provide their own funding for the enhancement of local power grids adjacent to the high-tension link, to the tune of 371 million Euro in Poland and 95 million Euro in Lithuania. Once again, the need for reducing the Baltic countries' dependence on Russian hydrocarbon imports, and improving the energy interconnections between them, was quoted as one of the main rationales for the investment. ${ }^{\text {xix }}$

Another well-publicised initiative that can be linked to the political tensions surrounding Nord Stream is the Odessa-Brody-Płock-Gdańsk oil pipeline, which is meant to be transporting Kazak and Azeri oil from the Black to the Baltic Sea coasts, via the Ukraine and Poland. The 674kilometre Ukranian leg of the pipeline, which was put into operation in 2002 and possesses a throughput capacity of 9 million tonnes (with the 
capability of reaching 14.5 million tonnes per annum), initially remained empty for almost three years because the Ukraine did not have the money required to fill it with Caspian crude oil, and neighbouring European states were unwilling to build the connecting pipelines needed to link Odessa-Brody to their respective refineries. ${ }^{\mathrm{xx}}$ As a result, the Ukraine signed an agreement with Russia in 2004 to 'reverse' the energy flow of the pipeline, by filing it with Russian oil that was then transported south towards the Black sea. However, although this development was seen in an unfavourable light by both the Polish and EU leadership, little was done by way of completing the Polish leg of the pipeline and establishing a flow of oil in the originally-intended South-North direction. ${ }^{\text {lxxi }}$ It is possible that the continued Russian determination to build Nord Stream and other similar energy networks in the region prompted the acceleration of such efforts in 2007 and 2008; this is evidenced by the Polish-Ukranian agreement, signed in April 2008, for a concrete development programme that would initially involve an assessment of the state of Ukraine's pipeline system and the investment necessary to bring it up to an international standard. ${ }^{\mathrm{lxxii}}$

Odessa-Gdańsk is part of an entire ensemble of new, mostly gas, pipelines that Poland intends to build in order to diversify its energy supply. One such link is the planned $1000 \mathrm{~km}$ gas pipeline to Norway, which has been on the drawing boards since 2001. Although the fate of this link remains unclear (due to the discrepancy between the high capital costs needed to build it, on the one hand, and the relatively small size of the Polish market, on the other), PGNiG has nevertheless taken an active role in the strengthening of energy relations between the two countries by purchasing stakes in Norwegian domestic gas licenses. ${ }^{\text {lxxiii }}$ The small size of the Polish gas market is also one of the main reasons why a planned gas pipeline to Denmark was never built.lxxiv There have also been proposals to construct a short pipeline to Germany; although this interconnection is deemed more profitable than the others, energy security concerns have also taken centre stage in this case, as it is likely that the pipes would be filled with Russian gas. lxxv

In recent years - and especially after the 2007 election victory of Tusk's Civic Platform government - Poland has taken a more active role in the development of alternative gas transit routes not only along its own borders, but the region more broadly. One of the key elements of the country's 'bold new foreign policy'lxxvi in the Baltic has been the proposed 'Amber' pipeline: an overland alternative to Nord Stream, traversing the territories of Latvia, Lithuania and Poland. Although this interconnection, initially proposed in October 2002, was supposed to supply Poland and Lithuania with gas from Denmark, Polish politicians have suggested that it may be filled with Russian gas as well. lxxvii Tusk's government has often relied on the 'Musketeers' pact' - an informal alliance of EU states, operating under the credo 'one for all and all for one' and aimed at improving energy exchanges within Europe - as an international political 
base for obtaining EU support for the pipeline. However, Amber's future remains uncertain as a result of Russia's lack of interest to build it, despite the purported lower construction and maintenance costs compared to Nord Stream.

The dramatic Russian-Ukrainian conflict over natural gas transit that unfolded during the winter of 2009 has been a mixed blessing for the Polish political position on Nord Stream. On the one hand, the dispute gave credence to the Russian stance about the unreliability of overland transit across its post-Communist neighbour states in ECE, thus reinforcing its justification for the construction of Nord Stream ${ }^{\text {lxxviii. On }}$ the other hand, however, the perception that gas export routes across the Ukraine are potentially risky revived the proposal to double the capacity of Yamal-Europe by constructing a second leg of this pipeline. lxxix It can be argued that the gas crisis also undermined Nord Stream itself, by putting into question the overall security of Russian hydrocarbon supplies. ${ }^{\operatorname{lxx} x}$ The fact that that a seemingly disconnected set of energy-related developments strongly influenced the fate of the Nord Stream proposal once again demonstrates the extent to which this pipeline is enmeshed in a much wider landscape of power networks and energy security relations that span the entire European space.

\section{CONCLUSION: A WEB OF PARADOXES}

This paper has examined some of the political narratives and policy actions contained in the Polish polity's reaction to the planned Nord Stream pipeline, with the aim of uncovering the underlying power relations and socio-spatial dimensions of this infrastructural object. The reviewed evidence suggests that Nord Stream is part of a much wider transboundary network of economic and political flows, that in their entirety form a variegated and complex landscape of power articulated through the spatial formations of ECE and the Baltic region. This is because the route of the pipeline has become the focal point of a wide range of political discourses and conflicts in the Baltic: its investors' choice of an undersea instead of an overland path has come to signify not only their perceived and 'real' political and economic interests, but has also served as a conduit for the expression of the surrounding states' national security concerns, environmental problems, foreign policy objectives and national identity struggles. As a result, the pipeline has been implicated in the emergence of several socio-spatial paradoxes, whose mutual interactions are contributing to the shaping of development trajectories in Poland, the Baltic region and ECE more widely.

The first such contradiction is related to the reasons for the pipeline proposal itself. It has emerged that there is a close relationship between the proposal to construct Nord Stream, on the one hand, and earlier conflcts over gas transit networks between Russia and Western Europe, on the other. In particular, it appears that the construction of the Yamal- 
Europe pipeline indirectly contributed to Gazprom's decision to build Nord Stream, because the economic and political disputes that were associated with it - especially with respect to the proposed Ukraine 'bypass' pipeline through Poland, and the recent Ukrainian-Russian gas crisis - gave Russia the public justification to avoid overland transit routes across ECE. The formal resolution of this conflict relieved Gazprom of the legal duty to build the pipeline's second leg, which would also run through Poland. Thus, although many of the parties involved in the construction of YamalEurope hoped that this link would help allay some of the political tensions in the region by giving more power to transit states and increasing the energy interdependencies between Russia and the EU, it actually created further conflicts between them. Paradoxically, Yamal-Europe encouraged Russia to build a very different new pipeline across the region, while decreasing the possibility that 'Amber' - which very much resembles this pipeline - would ever be constructed. ${ }^{\text {xxxi }}$

The second contradiction stems from Nord Stream's ability to simultaneously bind together and break apart the socio-spatial tissues and international co-operation frameworks of the Baltic region. It has done this in several ways. Although the proposal to build the pipeline exemplifies the successful co-operation between an EU state (Germany) and Russia - and could doubtless increase the territorial cohesion of the Baltic and ECE spaces by intensifying energy trade and interdependence across national boundaries - it has also worsened energy relations between a large part of the EU and Russia. Nord Stream has also exposed the weaknesses of the EU's internal decision-making mechanisms, since the bloc has been unable to respond to the problems linked to the pipeline through a unified energy policy. In many ways, the proposed gas link has driven a wedge through the heart of the economic and political fabric of the Baltic space, even though its declared purpose has been precisely the opposite: to forge new linkages between different parts of this geographical realm through a new socio-technical network.

One of the most surprising consequences of these developments is that although the level of political unity in the region has apparently decreased as a result of Nord Stream, the resulting tensions have led to the creation of new international political alliances, such as the 'Musketeers' pact. Thus, despite being an apple of discord in some cases, the pipeline proposal has actually strengthened the ties and connections among a number of Baltic and ECE states. As pointed out by Grigory Pasko, 'there's no need to keep repeating all the time that the project is for the integration of Europe: of the eight countries directly affected by the project, five are against it. And this has already become a factor of reintegration'.lxxxii

The third paradox embodied in the Nord Stream issue lies in the 'quasimaterial'lxxxiii nature of this infrastructural object per se: although its existence isn't physically 'real', the pipeline has started to exert very 
tangible effects on the 'real' landscapes of the surrounding countries, through the formulation and implementation of energy and economic development policies. This is exemplified by the Polish state's response to the new geopolitical dynamics brought by the pipeline: the country has aimed to diversify its energy supply by giving increased support to a number of new energy investment schemes, which, when built, are bound to deeply transform its economic, political and social geographies.

However, is that it Nord Stream's potential, rather than actual, material existence that has led to dramatic changes in national security discourses and their associated policies. As a result, although the Nord Stream proposal is topographically sited within a very strictly delineated route across the Baltic Sea, the pipeline has so far been 'performed' in topological space, through the heterogeneous networks associated with the political and economic forces behind it.

There is also some evidence to suggest that Poland's policy-makers and public actors have gradually moved from a reactive policy phase (whereby 'grand' narratives of national identity, historical power relations and the realpolitik of regional energy security were invoked in order to discursively accommodate Nord Stream within the country's geopolitical frame), to a proactive one, in which the country's polity developed a number of national and international policies aimed at destabilising the arguments that provided the grounds for the pipeline proposal as such. This process - and herein may lie a fourth paradox related to the pipeline - has in many ways paved the path for the construction of Nord Stream, by allowing the possibility (at least politically) that an 'alternative' gas link which would address its opponents' concerns will also be built at an indeterminate point in the future.

Speaking more broadly, the reviewed evidence suggests that international gas pipelines can impact a country's spatial formations both directly (through the physical structures associated with the pipelines themselves) and indirectly (by affecting national economic development and energy policies). Their agency is expressed through a networked web of relations, situated between the materialities of the intended route, on the one hand, and the geopolitical imaginations, historical narratives and policy decisions associated with them, on the other. Such infrastructures produce space in material and discursive terms alike, since they are both the culmination a hybrid socio-technical web of cross-border power relations, and an active place-maker with their own agentic capabilities. It has also transpired that gas pipelines are borne out of, and responsible for, the emergence and articulation of spatial contradictions and political conflicts among different states. However, the territorial contradictions created by the construction of one pipeline can only be resolved by building yet another one in its vicinity: in a way, these infrastructure networks reproduce each other through a landscape of paradox.

\section{NOTES}


i R. Sikorski, M. Olex-Szczytowski, and J. Rostowski, 'Russian gas pipeline would be geopolitical disaster for EU', Financial Times (28 May 2007); MosNews, 'Poland calls Baltic Gas pipeline Russian-German conspiracy', 8 Aug. 2005.

ii V. Socor, 'Baltic Seabed gas pipeline project: far from a done deal', available at http://www.jamestown.org/edm/article.php?article_id=2372178, accessed 26 May 2008.

iii J. Dempsey, 'Gas pipeline under the Baltic faces many hurdles', International Herald Tribune (6 May 2008); The New York Times, 'Baltic pipeline stalls 3 years after deal', 8 May 2008.

iv P. Rutland, Lost Opportunities: Energy and Politics in Russia (Washington, D.C.: The National Bureau of Asian Research, 1997).

v Socor (note 2) p. 2; also Radio Liberty/Radio Free Europe, 'Ukraine: OdessaBrody pipeline potential still unused', 12 Jan. 2007, available at http://www.rferl.org/featuresarticle/2007/01/a93dfee7-ec31-4862-af51-fddb54c2ca95.html, accessed on 26 May 2008.

vi Reuters, 'FACTBOX - 18 countries affected by Russia-Ukraine gas row', 7 Jan. 2009; BBC News, 'Italy hit by Russian gas shortage', 18 Jan. 2006, available at http://news.bbc.co.uk/1/hi/business/4625092.stm, accessed on 18 Jan. 2006.

vii E. Karm, 'Environment and energy: the Baltic Sea gas pipeline', Journal of Baltic Studies 39/2 (2008) pp. 99-121.

viii Kommersant, 'Russia ready to pay for independence from transit countries', 29 Jan. 2008; Nord Stream AG press release, 8 November 2007.

ix See, for example, G. Bridge, 'Global production networks and the extractive sector: governing resource-based development', Journal of Economic Geography 8/3 (2008) pp. 389-419; K. Bakker and G. Bridge, 'Material worlds? Resource geographies and the "matter of nature", Progress in Human Geography 30/1 (2006) pp. 1-23; R. Hayter, T. J. Barnes, and M. J. Bradshaw, 'Relocating resource peripheries in the core of economic geography's theorizing: rationale and agenda', Area 35/1 (2003) pp. 15-23.

x See, for example, W. Bijker, 'Do not despair: there is life after constructivism', Science, Technology and Human Values 18/1 (1993) pp. 113-138; J. Law and W. E. Bijker, 'Postscript: technology, stability, and social theory', in J. Law and W. E. Bijker, eds., Shaping Technology/Building Society: Studies in Sociotechnical Change (Cambridge, Mass.: MIT Press, 1992) pp. 291-308; M. Callon and B. Latour, 'Unscrewing the big Leviathan: how actors macro-structure reality and how sociologists help them to do so', in K. Knorr-Cetina and A. V. Cicourel, eds., Advances in Social Theory and Methodology (London: Routledge \& Kegan Paul, 1981) pp. 277-303.

xi T. P. Hughes, Networks of Power: Electrification in Western Society, 1880-1930 (Baltimore: Johns Hopkins University Press, 1993); J. Bennett, 'The agency of assemblages and the North American blackout', Public Culture 17/3 (2005) pp. 445-465; S. L. Star, 'The Ethnography of Infrastructure', American Behavioral Scientist 43/3 (1999) pp. 377-391; S. O'Lear, 'Oil frontiers \& local perceptions of export pipelines: the case of Baku-Tblisi-Ceyhan in Azerbaijan and Georgia', Paper presented at the 'Spaces of Politics: Concepts and Scales' International Political Geography Colloquium, 2-4 April 2008, Université de Reims Champagne Ardennes. Also see S. Graham and S. Marvin, Splintering Urbanism: Networked Infrastructures, Technological Mobilities, and the Urban Condition (London and New York: Routledge, 2001).

xii L. Dienes, 'Reflections on a geographic dichotomy: archipelago Russia', Eurasian Geography and Economics 43/6 (2002) pp. 443-458. Also see L. Dienes, I. Dobozi, and M. Radetzki, Energy and Economic Reform in the Former Soviet Union (London: Macmillan, 1994). The spatial extension of Russian political power through energy networks is discussed by, inter alia, M. M. Balmaceda, 'Gas, oil and the linkages 
between domestic and foreign policies: the case of Ukraine', Europe-Asia Studies 50/2 (1998) pp. 257-286; G. Winrow, 'Geopolitics and energy security in the wider Black Sea region', Southeast European and Black Sea Studies 7/2 (2007) pp. 217-235; G. Austin and M. Schellekens-Gaiffe, Energy and Conflict Prevention (Stockholm: Gidlunds förlag, 2007).

xiii For a similar study in relation to the Baku-Tbilisi-Ceyhan pipeline, see A. Barry, 'Materialist politics' in B. Braun and S. Whatmore, eds., Stuff Matters (Minneapolis: Minnesota University Press, 2009), forthcoming.

xiv M. B. Olcott, 'Pipelines and pipe dreams: energy development and Caspian society', Journal of International Affairs 53/1 (1999) pp. 305-324; K. Mehdiyoun, 'Ownership of oil and gas resources in the Caspian Sea', The American Journal of International Law 94/1 (2000) pp. 179-189; R. H. Dekmejian and H. H. Simonian, Troubled Waters. The Geopolitics of the Caspian Region (London: I. B. Tauris, 2001); G. Baghat 'Pipeline diplomacy: the geopolitics of the Caspian Sea region', International Studies Perspectives 3/3 (2002) pp. 310-327; S. O'Lear, Resources and conflict in the Caspian Sea, Geopolitics 9/1 (2004) pp. 161-186.

xv R. V. Barylski, 'Russia, the West, and the Caspian Energy Hub', The Middle East Journal 49/2 (1995) pp. 217-232; T. R. Stauffer, 'Caspian fantasy: the economics of political pipelines', The Brown Journal of World Affairs 7/2 (2000) pp. 63-78; P. Kubicek, 'Russian energy policy in the Caspian Basin', World Affairs 166/4 (2004) pp. 207-217.

xvi A. P. Tsygankov, 'Mastering space in Eurasia: Russia's geopolitical thinking after the Soviet break-up', Communist and Post-Communist Studies 36/1 (2003) pp. 101127; H. Balzer, 'The Putin thesis and Russian energy policy', Post-Soviet Affairs 21/3 (2005) pp. 210-225.

xvii See F. Hill, Energy Empire: Oil, Gas and Russia's Revival (London: The Foreign Policy Centre, 2004); European Voice, 'The EU must unite to reduce Gazprom's leverage', 22 Feb. 2008; C. R. Saivetz, 'Russia: An Energy Superpower?' available at http://www.alternet.org/audits/75413/, accessed 5 Feb. 2008; E. L. Morse and J. Richard, 'The Battle for Energy Dominance', available at http://www.foreignaffairs.org/ 20020301faessay7969/edward-l-morse-james-richard/the-battle-for-energydominance.html, accessed 26 May 2008. The possibility of a rapid increase in Russian oil and gas production is seen with scepticism by all of these authors, because of the aging of the main fields in West Siberia (which account for 80 per cent of Russian output), and the technically difficult development of offshore fields in the Arctic North of Russia.

xviii D. J. Galbreath and J. W. Lamoreaux, 'Bastion, beacon or bridge? Conceptualising the Baltic logic of the EU's neighbourhood', Geopolitics 12/1 (2007) pp. 109-132.

xix M. Leonard and N. Popescu, A Power Audit of EU-Russia Relations (London: European Council on Foreign Relations, 2007).

xx Magyar Hírlap, 'EU disunity means increasing dependence and gas prices', 26 March 2008; V. Socor, 'A political summit might resuscitate the Nabucco project', available at http://jamestown.org/edm/article.php?article_id=2373244, accessed on 13 Aug. 2008; A. Wilson and M. Leonard, 'Poisonous relations', Newsweek (28 July 2008); Sunday's Zaman, 'Costly South Stream a chance for Nabucco', 3 Aug. 2008.

xxi M. Natorski and A. Herranz, 'The impact of German-Russian and PolishUkranian special relations on European foreign policy: energy supplies and visas in the EU neighbourhood', Journal of Constitutional Law in Eastern and Central Europe 14/2, (2007) pp. 215-223.

xxii D. Johnson, 'EU Russian energy links: a marriage of convenience? Government and Opposition 40/2 (2005) pp. 256-277; J. Hughes, 'EU relations with Russia: partnership or asymmetric interdependency?' in N. Casarini, ed., European 
Foreign Policy in an Evolving International System: The Road Towards Convergence (New York: Palgrave, 2007), pp. 76-94.

xxiii $B B C$ News, 'Putin firm on EU energy charter', 21 Oct. 2006, available at http://news.bbc.co.uk/2/hi/europe/6068386.stm, accessed 10 Aug. 2008.

xxiv A. V. Belyi, 'New dimensions of energy security of the enlarging EU and their impact on relations with Russia', European Integration 25/4 (2003) pp. 351-369.

${ }^{x x v}$ A. Markandya, V. Costantini, F. Gracceva, and G. Vicini, Security of Energy Supply: Comparing Scenarios From a European Perspective (Milano: Fondazione Eni Enrico Mattei, 2005).

xxvi G. Klaassen, A. McDonald, J. Zhao, 'The future of gas infrastructures in Eurasia', Energy Policy 29/5 (2001) 399-413.

xxvii C. von Hirschhausen, B. Meinhart, and F. Pavel, 'Transporting Russian gas to Western Europe - a simulation analysis', The Energy Journal 26/5 (2005) pp. 49-68.

xxviii A. A. Makarov and V. L. Likhachev, 'Diversification of Russian gas export routes', International Journal of Global Energy Issues 18/1 (2002) pp. 69-83.

xxix In early 2009, it was announced that the French company GDF Suez is also interested in buying a minority stake in the pipeline (Vedomosti, 'Nord Stream consultations enter final straight', 6 March 2009)

xxx G. Pasko, 'Déja-vu in Brussels', available at

http://www.robertamsterdam.com/2008/02/grigory_pasko_dejavu_in_brusse.htm, accessed on 26 May 2008;

xxxi Initially the pipeline consortium was planning to build a service platform directly above the compressor station which lies midway through the pipeline route (at a location $68 \mathrm{~km}$ north-east of the Swedish island of Götland). However, these plans were abandoned in response to fierce environmental opposition in Sweden (Marinelink.com 'Nord Stream withdraw to build service platform', available at http://www.marinelink.com/Story/NordStreamWithdrawtoBuildServicePlatform211436.html, accessed on 14 Aug. 2008; EU Energy, 'Nord Stream says no need for service platform in Swedish waters', 18 April 2008).

xxxii Kauppalehti, 'Sweden demands further clarification about pipeline', 13 Feb. 2008; Helsingin Sanomat, 'Baltic Sea gas pipe project meets large difficulties', 11 March 2008.

xxxiii Latvijas Avize, 'Nord Stream - neighbours object, Latvia abstains', 30 Jan. 2008.

xxxiv Eurometri, 'Nord Stream conducting environmental assessment in the summer', available at http://www.suomeneurooppaliike.fi/eurometri/1eurometri2007/sivu24.pdf, accessed on 15 Aug. 2008; expert interview in Gdansk, 18 Apr. 2008.

xxxv See note 31.

xxxvi See Dempsey (note 3).

xxxvii Ibid.

xxxviii G. Raguzina, 'While Nord Stream embraces Russia, Estonia will not embrace Nord Stream', 2 Nov. 2007, available at http://www.bellona.org/articles/articles_2007/Nord_stream, accessed on 10 Aug. 2008.

xxxix See Marinelink.com (note 31).

xl Russia today, 'Poland spoils Nord Stream's game', 27 Aug. 2007. 
xli Reuters, 'Nord Stream delays first gas exports to 2011', 21 Dec. 2007; Reuters, 'Gazprom says Nord Stream pipeline to cost more', 11 Feb. 2008.

xlii Deutche Welle, 'German-Russian Baltic Sea gas pipeline delayed', 24 July 2008, available at http://www.dw-world.de/dw/article/0,2144,3509088,00.html, accessed on 14 Aug. 2008.

xliii Engineer Live, 'Offshore pipeline across Baltic will secure Europe's gas supply', available at http://www.engineerlive.com/international-oil-and-gasengineer/produ...offshore-pipeline-across-baltic-will-secure-europes-gas-supply.thtml, accessed on 14 Aug. 2008.

xliv Among other points, the report stated that the Nord Stream consortium had considered various routes and concluded that 'the off-shore route turns out to be the more environmentally friendly' since a land-based route would 'cross ecologically sensitive areas on land and possibly conflict with alternative land use' (Deutche Welle, 'Nord Stream pipeline presents project report', 11 Aug. 2008, available at http://www.dwworld.de/dw/article/0,2144,3555572,00.html, accessed on 14 Aug. 2008).

xlv United Press International, 'Nord Stream report due in March', 19 Feb. 2009; United Press International, 'Officials: Nord Stream ESA right step', 12 March 2009.

xlvi Steel Guru, Nord Stream delays first delivery of gas, 13 Aug. 2008, available at http://steelguru.com/news/index/2008/07/15/NTQ4NDA\%3D/Nord_Stream_delays_first_d elivery_of_gas.html, accessed on 14 Aug. 2008.

xlvii A. Heinrich, Poland as a Transit Country for Russian Natural Gas: Potential for Conflict (Koszalin: Koszalin Institute of Comparative European Studies, 2007).

xlviii Interview with official in Polish presidential cabinet, Warsaw, 5 June 2008.

xlix Ibid, p. 30.

1 Ibid, p. 44.

li J. Laurila, 'Transit transport between the European Union and Russia in light of Russian geopolitics and economics' Emerging Markets Finance and Trade 39/5 (2003) pp. $27-57$. 2008).

lii Hotten, R. 'What's in the pipeline for Nord Stream?' Daily Telegraph (21 Feb.

liii For a further discussion, see Heinrich (note 47).

liv Ibid, p. 32.

lv N. Watson, 'Poland plots downfall of Russia's Nord Stream pipeline with allies' help', Russia Profile.org, 24 Jan. 2008, available at

http://www.russiaprofile.org/page.php?pageid=Business + New+Europe\&articleid=a12011 66714, accessed on 7 Aug. 2008.

lvi In fact, there is no such thing as a formal EU 'energy solidarity' principle, although it was foreseen, inter alia, by a European Commission Green Paper titled 'A European Strategy for Sustainable, Competitive and Secure Energy' published on the 8 March 2006. Polish politicians have constantly called for this principle to be established at the EU level (see, for example, Europe Energy, 'Poland wants a mandate emphasising energy solidarity with EU', Feb. 2008, available at http://findarticles.com/p/articles/mi_hb6638/is_200802/ai_n26528655, accessed on 5 Aug. 2008). For a broader critique of the EU's inability to formulate a common energy policy see Kovačovská L., European Union's Energy (In)Security - Dependency on Russia (Prague: Association for International Affairs, 2007); Q. Perret, 'The EU, Russia and gas: intimations of mortality and supremacy of politics', Lithuanian Foreign Policy Review 2006/18 (2006) pp. 167-181. 
lvii Sikorski et al. (note 1).

lviii Ministry of Economy Official press release, available at http://www.mg.gov.pl/English/News/pipeline+nord+stream.htm, accessed on 26 May 2008.

lix Gazeta Wyborcza, 'Gaz i ropa - Rosja buduje swą pozycję w UE', 8 Sep. 2005.

lx Wprost 24, 'Polska szantażuje Rosję?!', 7 Sep. 2005.

lxi Gazeta Wyborcza, 'Stawka większa niż rura', 11 Jan. 2006.

lxii Polskie Radio, 'Kwasniewski's Russian gas pipeline support "scandalous", 17 July 2008; $P A P$, 'Polish cx-President criticized over comments about Nord Stream project', 18 July 2008.

lxiii Deutsche Welle, 'Poland's veto a setback for EU-Russia talks', 24 Nov. 2006, available at http://www.dw-world.de/dw/article/0,2144,2247414,00.html, accessed on 5 Aug. 2008; RIA Novosti, 'Polish veto an internal EU problem - Sergei Yastrzhembsky', 25 Oct. 2007, available at http://en.rian.ru/analysis/20071025/85492771.html, accessed on 7 Aug. 2008.

lxiv For a good overview of this process see Platts Energy in East Europe, 'Poland looks to end reliance on Russian energy', available at http://www.platts.com/Natural\%20Gas/Resources/News\%20Features/ukrainegas/index.x $\underline{\mathrm{ml}}$, accessed on 7 Aug. 2008.

lxv Zarząd Morskich Portów Szczecin i Świnoujście SA, 'We won', available at http://www.port.szczecin.pl/angielska/news/12_2006/We_won.htm, accessed on 10 Aug. 2008.

lxvi Financial Times, 'Polish gas supplier to buy into Norwegian gas fields', 1 March 2007.

lxvii Reuters, 'FACTBOX-Nuclear projects in central and southeast Europe', 27 July 2008; Dziennik Baltycki, 'Rząd chce nas przekonać do atomu. Powtórka z Żarnowca?', 7 July 2008; Tygodnik Ostrołęcki, 'Strach przed atomem’, 21 July 2008.

lxviii Taimre, S. 'Polish energy companies agreed on atomic development venture', 28 July 2008, available at http://balticbusinessnews.com/Print.aspx?ArticleID=296ce6b170f6-4669-9381-8d11b3cf5144, accessed on 2 Aug. 2008.

lxix $D P A$, 'Poland, Lithuania establish company for energy link construction', 19 May 2008.

lxx Radio Liberty/Radio Free Europe, 'Ukraine: Odessa-Brody Pipeline Potential Still Unused', available at http://www.rferl.org/featuresarticle/2007/01/a93dfee7-ec314862-af51-fddb54c2ca95.html, accessed on 26 May 2008. This report cites 'Stratfor Commentary', who noted that as a result of the lack of export partners for the OdessaBrody pipeline, 'Kiev found itself saddled with a white elephant rusting picturesquely in the Ukrainian countryside'.

lxxi Ibid. An EU-supported multinational consortium including Polish Lithuanian, Georgian, and Azerbaijani shareholders has been working on plans for the Polish section of the line since 2007 , but with little visible progress.

lxxii New Europe, 'Kaczyski, Yushchenko agree on Odessa-Brody-Plock-Gdansk', 21 April 2008.

lxxiii Financial Times (note 66); also see Heinrich (note 47).

lxxiv Pipeline and Gas Journal, 'Poland, Denmark Sign Deal For Gas Pipeline', Aug. 2001, available at http://findarticles.com/p/articles/mi_m3251/is_8_228/ai_n25036012, accessed on 26 May 2008. 
lxxv Warsaw Business Journal, 'Bartimpex hopes to build new gas pipeline by 2006, 27 Feb. 2006.

lxxvi C. Grant, 'Poland's bold new foreign policy', Centre for European Reform Bulletin 58/Feb. (2008), available at http://www.cer.org.uk/articles/58_grant.html, accessed on 26 May 2008.

lxxvii Globalinsight.com, 'Baltic, Polish leaders rejuvenate Amber Gas pipeline proposal as alternative to controversial Nord Stream', 6 Feb. 2008, available at http://www.globalinsight.com/SDA/SDADetail11482.htm, accessed on 17 Aug. 2008.

lxxviii Russia Today, 'Gas crisis focuses minds on new routes', 9 Jan. 2009.

lxxix Y. Humber, 'Belarus seeks to double Russian gas flows, challenging Ukraine', Bloomberg, 13 March 2009; Polish Market Online, 'Poland looks forward to second Yamal gas pipeline', 10 March 2009, available at http://www.polishmarket.com.pl/document/:19421?p=\%2Flate\%2F, accessed on 12 March 2009.

lxxx See, for example, Euronews, 'Energy strategy to avoid Russia', 19 Feb. 2009.

lxxi As pointed out by Heinrich (note 47) 'The analysed conflicts converged; conflicts about the Yamal and bypass pipelines were the precondition and trigger for the construction of the Nord Stream pipeline leading to the next conflict' (p. 85).

lxxxii Pasko (note 26).

lxxxiii For a wider discussion, see, for example, A. Pottage 'Power as an art of contingency: Luhmann, Deleuze, Foucault', Economy and Society 27/1 (1998) pp. 1-27. 